\title{
Teaching Mode to Promote Autonomy Learning in Multimedia and Network Environment
}

\author{
Ying Zhan, Hong Li, Yuanyuan Xing \\ Xi'an High-Tech Institute \\ Xi’an, China \\ 365894034@qq.com
}

\begin{abstract}
For the last few decades, the dominated learning theory had transmitted from Behaviorism to constructivism. As a result, a large number of language scholars and educators have paid much emphasis on learners, aiming at cultivating them autonomous learners. The traditional "chalk and talk" teaching mode meets a challenge. Thus, it is inevitable to reform the method of college English teaching. And there are a considerable number of language teachers and researchers are trying every means to find some suitable approaches to enhance their teaching and improve students' learning. The introduction of computer and network to classes paves the way for the reform of the second language teaching and learning. The present study of this paper endeavors to present a new teaching mode of promoting students' autonomous learning of English; classroom observation is to figure out the features of the innovated teaching mode; questionnaire is utilized for data collection, aiming at seeking information about students' opinions on the new teaching mode. Moreover, performances in different examinations or of the different classes were compared to indicate that the innovated teaching mode is effective in promoting language teaching and autonomous learning.
\end{abstract}

Keywords-learning theories; college English teaching and learning; autonomy learning; multimedia network

\section{INTRODUCTION}

As a result of increasing college enrollment, nowadays, many universities in China are facing the same problems in English teaching such as big classes, students of different levels, limited in-class periods and a lack of teachers and so on. And the traditional language-teaching approach met a challenge. In the last three decades, multimedia and network technologies have progressed by leaps and bounds. With this rapid progress, it has become feasible and affordable to integrate these technologies into teaching and learning process. Therefore, the Ministry of Education has drawn up the new College English Curriculum Requirements, focusing on cultivating learner autonomy, encouraging the use of multimedia and network technology in college English education. However, how to use these technologies effectively to enhance English teaching and learning process is still a great concern both to language teachers and scholars. With such a consideration, the authors did a study to present the autonomy learning mode adopted by the department of Foreign Language Education in one Poly-technique University in Xi'an, which proved to be efficient to meet the needs of the New College English Curriculum Requirements and make students autonomous learners.

Literature Review

Learning theories:
For the last few decades, the dominated learning theory had transmitted from Behaviorism to constructivism. Behaviorism defines learning as a passive accumulation of information, which put more emphasis on teaching, while constructivism shifts the responsibility of learning to the student. Compared with what the behaviorists believe---the teacher feeds progressively more difficult bits of data to the student in class, constructivists believe that "knowledge is constructed by the learners as they attempt to make sense of their experiences" (Driscoll, 1994). This learner-centered approach sees the student actively constructing knowledge. The teacher's role is to guide students to learn by themselves through the process of learning.

\section{A. Autonomy learning}

The concept of autonomy has been around for a few years and even become a buzzword within the context of language learning. Holec (1981) defines autonomy as "the ability to take charge of one's own learning”. Dickinson (1987) states that autonomy is a "situation in which the learner is totally responsible for all of the decisions concerned with his or her learning and implementation of those decisions". That does mean the learner should have much of the responsibility for planning and organizing their learning, for doing it, for assessing its value to him or herself and even for suggesting the mark that the work produced should get.

According to the theories mentioned above, autonomy learning is without doubt the best way to reach our educational goal. McDevitt (1997) points out "the end product of education is an independent learner", "and that cultivating a learner's independence or autonomy should be regarded as the end goal that teachers or educators try to pursue” (Li Ming, 1997).

\section{RESEARCH DESIGN}

\section{A. Subjects}

In this study, the participants were 600 non-English majors, who had passed the placement test in 2011 and were placed into different classes. Among them, 150 were placed randomly in multimedia and web-based classroom, the rest in traditional classroom.

\section{B. Instruments}

Questionnaire and observation are utilized for data collection in this study. Questionnaire aims to seek information about students' opinions on the new teaching mode while observation focuses on the teaching mode adopted in the university. 


\section{Procedures}

First, the authors did classroom observation at the very beginning of the semester of 2011-2012. And this kind of observation lasted for the two semesters. After the students finished one-year College English learning, they were asked to complete a questionnaire, the purpose being to seek information about students' opinions on the new teaching mode. Meanwhile, the authors compared the scores of different tests in order to test the efficiency of this mode.

\section{DATA COLLECTION AND RESUlTS}

\section{A. Data from Observation}

With one-year classroom observation (from September, 2011 to July, 2012), the author concludes that the teaching mode adopted by the teachers in this university to improve autonomy learning goes through three stages: teacher-instructed individualized autonomy learning; teacher-instructed separated autonomy learning; non-instructed autonomy learning.

Teacher-instructed autonomy learning lasted for 10 weeks (from 1st week to the 10th week). During this period, teachers try their best to help their students master the skills of autonomy learning on internet and organize their learning, through which improve students learning interests.

Teacher-instructed separated autonomy learning needed another 10 weeks of the academic year--- from the 11th week to 15th week of the first semester and from 1st week to 5th week of the second semester. After the first-stage training, students had mastered some autonomy learning skills. The main task of teachers in this period is to instruct students separately in accordance with their own studies. In this way, students can acquire some information about teaching contents, learning instructions, teachers' assessments as well as feedback.

The last stage is for non-instructed autonomous study, from the 6th week to the 15th week of the second semester, in which students "instruct" themselves when they are learning. That is to say, they can realize the procedure of autonomy learning---self-identifying, self-choosing, self-developing and self-controlling. The major role of teachers is assessing the results of learning.

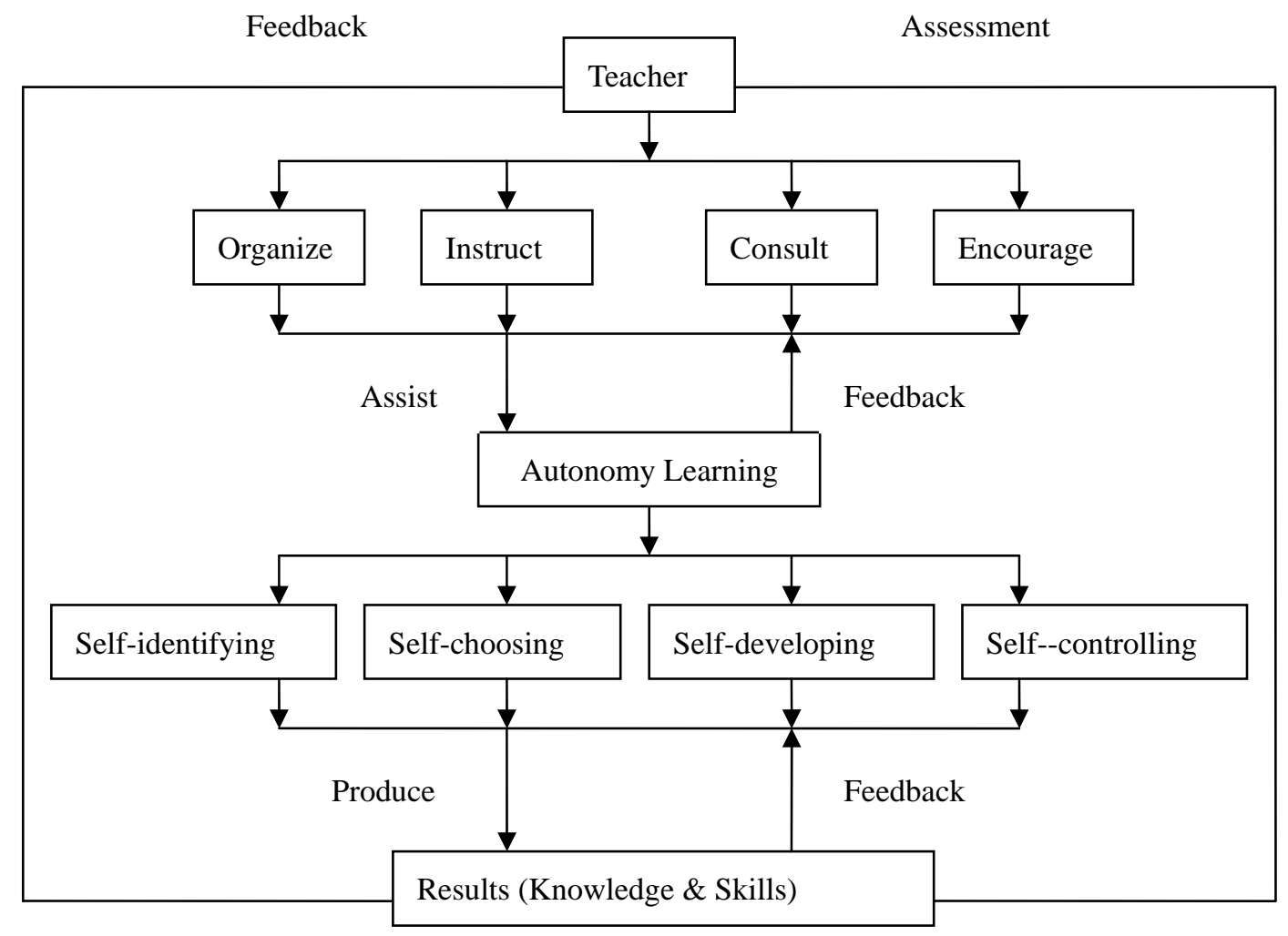

FIGURE I. AUTONOMY LEARNING MODE

\section{B. Data from Questionnaire} table.

The questionnaire results are illustrated in the following 
TABLE I. QUESTIONNAIRE RESULTS OF STUDENTS’ ATTITUDES TOWARDS CURRENT LEARNING MODE

\begin{tabular}{|l|l|l|l|l|l|}
\hline \multicolumn{1}{|c|}{ Qer. } & \multicolumn{1}{c|}{$\begin{array}{c}\text { Strongly } \\
\text { agree }\end{array}$} & \multicolumn{1}{c|}{ Agree } & \multicolumn{1}{c|}{ Not sure } & \multicolumn{1}{c|}{ Disagree } & \multicolumn{1}{c|}{$\begin{array}{c}\text { Strongly } \\
\text { disagree }\end{array}$} \\
\hline Q1 & $59 \%$ & $28.2 \%$ & $3.4 \%$ & $8 \%$ & $1.4 \%$ \\
\hline Q2 & $32.43 \%$ & $39 \%$ & $15.08 \%$ & $9.3 \%$ & $4.19 \%$ \\
\hline Q3 & $56.01 \%$ & $23.19 \%$ & $11.7 \%$ & $6.9 \%$ & $2.2 \%$ \\
\hline Q4 & $44 \%$ & $32 \%$ & $18.5 \%$ & $4.2 \%$ & $1.3 \%$ \\
\hline Q5 & $59 \%$ & $18 \%$ & $9 \%$ & $12 \%$ & $2 \%$ \\
\hline Q6 & $15 \%$ & $61.2 \%$ & $22.4 \%$ & $1.4 \%$ & $/$ \\
\hline Q7 & $25 \%$ & $47 \%$ & $17 \%$ & $8 \%$ & $3 \%$ \\
\hline Q8 & $\begin{array}{l}\text { Listening } \\
(54.5 \%)\end{array}$ & $\begin{array}{l}\text { Speaking } \\
(32 \%)\end{array}$ & $\begin{array}{l}\text { Reading } \\
(8.3 \%)\end{array}$ & $\begin{array}{l}\text { Writing } \\
(7.2 \%)\end{array}$ & \\
\hline
\end{tabular}

Table 1 indicates that most students hold the positive attitudes towards the current teaching mode adopted by the Department of Foreign Language Education in the university. As to question $1,59 \%$ students strongly agree and $28.2 \%$ agree that the current web-based learning is more effective to promote the interest of learning English; 71.43\% students think that compared with the traditional teaching mode, they become more confident to study English in web-based classroom; as to questions 5,6,7, concerning learning independently, more than $70 \%$ students show that the current teaching mode gives them more confidence in choosing learning tasks, more freedom in controlling learning pace and thus promotes their abilities to learning English on their own.

\section{Scores Comparisons}

In order to test the efficiency of the innovated teaching mode, with the help of the department leader, the authors made the comparison between the scores of the students in their placement test and those in their final examination; the comparison between the scores of one randomly selected web-based classroom students in final examination and those of one traditional classroom students in the same examination. The results are as follows.

TABLE II. SCORES COMPARISON BETWEEN PLACEMENT TEST AND FINAL EXAM

\begin{tabular}{|c|c|c|c|c|}
\hline Items & Highest Score & Lowest Score & Mean & Std. Deviation \\
\hline Placement test & 82.5 & 3.0 & 54.4403 & \\
\hline Final exam & 94.0 & 22.0 & 67.0401 & 10.82 \\
\hline
\end{tabular}

This table shows that the students make much progress after one-year college English learning, compared with their performances in the placement test which held at the very beginning of their college life. The highest score rose to 94 and the lowest 22 while in placement test, they were 82.5 and 3.0 respectively. To some extent, the significant differences of their performances can be attributed to the application of multimedia and network technology.

Then, the students' performances of the final examination held in July, 2012 were compared.
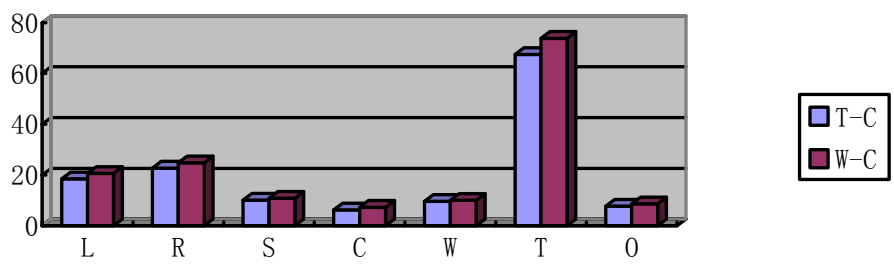

FIGURE II. SCORES COMPARISON BETWEEN WEB-BASED CLASSROOM AND TRADITIONAL CLASSROOM

T-C: TRADITIONAL CLASSROOM W-C: WEB-BASED CLASSROOM

L: LISTENING; R: READING; S: STRUCTURE; C: CLOZE
W: WRITING;
T: TOTAL;
O: ORAL 
The Web-based classroom consisted of four small classes, each with number 4131, 4132, 4232, 4234. And the Traditional classroom is made up of four small classes, each with number 3731, 8237, 11831, 13531. The students both in web-based classrooms and in traditional classrooms were required to take a final exam in July, 2012. Then we compared their performances in each item, which were classified into listening, reading, structure, cloze, writing, oral English and total performance. Figure 1 indicates that the average score of web-based classroom was higher than that of the traditional classroom. Moreover, as for as each item of the test concerned, the web-based classroom students did more successful job than their counterparts in traditional classroom.

\section{CONCLUSION}

Based on the author's one-year class observations and the students' overwhelmingly positive responses to the questions set in questionnaire, which, for most part, are the information about current-adopted college English teaching mode, we have enough evidence to conclude that multimedia and network technologies can be used as an effective way to enhance college language teaching and learning. Furthermore, in accordance with scores comparison, the "three-stage autonomy learning mode" proved to be efficient to make students more interested in learning English, confident in choosing learning tasks and free in controlling learning pace, thus promote students' abilities to learn English independently.

\section{REFERENCES}

[1] Dickinson, L. Self-instruction in Language Learning. Cambridge: Cambridge University Press, 1987.

[2] Freeman, D. L. \& Long, M. H. An introduction to second language acquisition research. Longman Group UK Limited, 2000.

[3] Gardner, D \& Miller, L. Establishing self-access from theory to practice. Cambridge University Press, 2002.

[4] Holec, H. Autonomy and Foreign Language Learning. Oxford: Pergamon Press, 1981.

[5] Li Ming. "Learner autonomy and the need for learner training in ELT in China", Teaching English in China, Issue 33, March 1999.

[6] McDevitt, B. "Learner autonomy and the need for learner training”, Language Learning Journal, September 1997.

[7] Bai Shuqin, Jing Jiangbao, "Promoting Autonomous Learning in Chinese English Teaching: from theory to practice", Teaching English in China, September 2003.

[8] He Lianzhen, "Autonomous Learning and Cultivation", Foreign Language Teaching, July 2003.

[9] Wang Xiaoling, "Autonomous Learning Theories and Application in China", Teaching English in China, June 2002.

\section{Appendix}

Questionnaire on students’ attitudes

1. The current Web-based learning is more effective in promoting my interest in English learning.
A. strongly agree
B. agree C. not sure
D. disagree E. strongly disagree

2. The current Web-based learning gives me more confidence in English learning.
A. strongly agre
B. agree C. not sure
D. disagree E. strongly disagree

3. The current Web-based learning makes me willing to spend more time in English learning.
A. strongly agree
B. agree
C. not sure
D.
disagree E. strongly disagree

4. I prefer this Web-based learning mode.
A. strongly agree
B. agree
C. not sure
D. disagree E. strongly disagree

5. The current Web-based learning is more effective in promoting my ability to learn English on my own.
A. strongly agree
B. agree C. not sure
D. disagree E. strongly disagree

6. The current Web-based learning gives me more freedom in controlling learning pace.
A. strongly agree
B. agree C. not sure
D. disagree E. strongly disagree

7. The current Web-based learning gives me more confidence in choosing learning tasks.
A. strongly agree
B. agree C. not sure
D. disagree E. strongly disagree

8. Which of the following skills have been improved in your past 1 year's learning through Web-based learning?
A. listening
B. speaking
C. readingD. writing E. 